\title{
BAHAN AJAR BERBASIS TIK PADA DIKLAT TEKNIS FUNGSIONAL PENINGKATAN KOMPETENSI PENGAWAS MADRASAH/PAI DI BALAI DIKLAT KEGAMAAN MAKASSAR
}

\author{
Dr. Ma'arif, M,Pd,I', Ratna Prilianti, S.Si, M.Pd² \\ ${ }^{1}$ Badan Litbang dan Diklat Kementerian Agama \\ ${ }^{2}$ Badan Litbang dan Diklat Kementerian Agama \\ 1ariefam1975@gmail.com; ${ }^{2}$ ratna.prilianti@gmail.com
}

d.

https://doi.org/10.36052/andragogi.v9i1.217

Diterima: 6 April 2021 | Disetujui: 2 Juni 2021 | Dipublikasikan: 30 Juni 2021

\begin{abstract}
Abstrak
Penelitian bertujuan untuk mengevaluasi bahan ajar berbasis TIK pada Diklat Teknis Fungsional Peningkatan Kompetensi Pengawas Madrasah/PAI di Balai Diklat Keagamaan Makassar. Evaluasi ini meliputi aspek substansi materi, desain pembelajaran, tampilan/komunikasi visual dan pemanfaatan software. Penelitian ini merupakan penelitian kualitatif dengan bentuk studi kasus. Pengumpulan data dilakukan melalui wawancara, observasi dan dokumentasi. Sedangkan analisis datanya menggunakan analisis data kualitatif dengan cara: reduksi data, sajian data, dan penarikan kesimpulan serta verifikasi. Hasil penelitian menyimpulkan bahwa meskipun pada beberapa aspek-aspek tersebut masih memerlukan perbaikan, tetapi pada umumnya kualitas bahan ajar yang digunakan oleh widyaiswara di Balai Diklat Keagamaan Makassar sudah cukup baik. Pemahaman widyaiswara tentang aspek-aspek yang harus diperhatikan dalam pembuatan bahan ajar berbasis TIK harus terus ditingkatkan dalam bentuk implementasi yang riil yaitu produk bahan ajar berbasis TIK yang baik. Penguasaan TIK merupakan sebuah kemutlakan bagi para widyaiswara serta harus adanya dukungan manajemen yang kuat dalam mendorong para widyaiswara untuk menyusun dan mengembangkan bahan ajar yang dapat menunjang pencapaian tujuan diklat.
\end{abstract}

Kata Kunci: Evaluasi, Bahan Ajar Berbasis TIK, Diklat Pengawas Madrasah/PAI

\begin{abstract}
[TEACHING MATERIALS BASED ON ICT ON THE FUNCTIONAL TECHNICAL TRAINING OF THE COMPETENCE IMPROVEMENT OF MADRASAH/ISLAMIC EDUCATION SUPERVISORS AT RELIGIOUS TRAINING CENTER OF MAKASSAR]. The researchs' aim is evaluate teaching materials based on ICT on the Functional Technical Training of the Competence Improvement of Madrasah/Islamic Education supervisors at Religious Training Center of Makassar. This evaluation includes aspects of the substance of the material, design of the learning, appearance/visual communication and the use of the software. This research is a qualitative research with a case study form. The data collecting through interviews, observation and documentation. While the data analysis uses qualitative data analysis by: data reduction, data presentation, conclusion drawing and verification. The results showed that eventhough some of these aspects still needed improvement, in general the quality of teaching materials used by trainer at Religious Training Center of Makassar was good enough. Trainers' understanding of the aspects that must be considered in making teaching materials based on ICT must be continuously improved in the form of real implementation, namely good teaching materials based on ICT. For that reason, mastery of ICT is an absolute for the trainers and there must be strong management support in encouraging trainers to compile and develop teaching materials that can support the achievement of the training objectives.
\end{abstract}

Keywords: Evaluation, Teaching Material Based on ICT, Functional Technical Training of the Competence Improvement of Madrasah/Islamic Education supervisors 


\section{PENDAHULUAN}

P erkembangan teknologi informasi dan komunikasi merupakan salah satu sebab perubahan paradigma baru pendidikan abad 21. Dalam konteks pemanfaatan teknologi informasi dan komunikasi di dunia pendidikan, telah terbukti semakin menyempitkan dan meleburkan "ruang dan waktu" yang selama ini menjadi aspek penentu kecepatan dan keberhasilan penguasaan ilmu pengetahuan. Sejalan dengan itu, kemajuan teknologi informasi dan komunikasi menyebabkan sebagian besar tenaga manusia digantikan oleh mesin yang akan lebih banyak melakukan tugas rutin, sementara manusia akan lebih banyak bergelut dengan tugas-tugas yang bersifat intelektual dan kreatif \{Formatting Citation\}.

Kecenderungan perubahan dan inovasi dalam dunia pendidikan akan terus terjadi dan berkembang dalam memasuki abad ke-21 sekarang ini. Perubahan tersebut antara lain dapat dilihat dari lebih mudahnya mencari sumber belajar, lebih banyak pilihan untuk menggunakan dan memanfaatkan TIK, makin meningkatnya peran media dan multimedia dalam kegiatan pembelajaran, dan lain-lain. Kecenderungan perubahan dan inovasi tersebut tentunya memiliki implikasi yang sangat luas dalam dunia pendidikan, yaitu: 1) Perubahan dalam program pembaruan dan teknologi pembelajaran, dan 2) Perubahan dalam belajar dan pembelajaran dengan menggunakan metode eksperimental, fokus belajar lebih pada peserta didik, peningkatan kompetensi intelligence quotient (IQ) yang juga diimbangi dengan emotional quotient (EQ) dan spiritual quotient (SQ) yang menuntut pengintegrasian TIK dalam pembelajaran (Hasan et al., 2019).

Pembelajaran melalui media televisi atau video, pembelajaran berbasis komputer (PBK), pembelajaran berbasis web (e-learning), pembelajaran berbantukan komputer (CAl), pembelajaran berbasis media presentasi/elektronik (AVA), adalah beberapa bentuk pemanfaatan TIK yang perlu dikembangkan dan dilaksanakan dalam dunia pendidikan dewasa ini. (Rusman, 2011: 4) Hal ini karena kegiatan pembelajaran merupakan bagian yang paling pokok dalam keseluruhan proses pendidikan. Ini berarti bahwa konsekuensi dari pencapaian tujuan pendidikan banyak tergantung pada bagaimana proses pembelajaran dirancang dan dijalankan secara profesional. Setiap kegiatan pembelajaran selalu melibatkan dua pelaku aktif, yaitu pendidik dan peserta didik. Pendidik merupakan pencipta kondisi belajar peserta didik yang didesain secara sengaja, menantang, sistematis, dan berkesinambungan. Sedangkan peserta didik merupakan pihak yang "menikmati" kondisi belajar yang diciptakan pendidik.

Salah satu permasalahan pendidikan yang kemudian menjadi prioritas pemerintah saat ini dan yang segera perlu dicarikan pemecahannya adalah kualitas pendidikan, khususnya kualitas pembelajaran. Dari berbagai kondisi dan potensi yang ada, upaya yang dapat dilakukan berkenaan dengan peningkatan kualitas di lembaga pendidikan adalah mengembangkan pendekatan pembelajaran yang berorientasi pada peserta didik (student centered) dan menfasilitasi kebutuhan peserta didik akan kebutuhan belajar yang menantang, aktif, kreatif, inovatif, efektif dan menyenangkan dengan mengembangkan dan menerapkan pembelajaran berbasis teknologi informasi dan komunikasi.

Rosenberg dalam Yaumi menyatakan bahwa perkembangan teknologi informasi telah membawa dampak yang begitu besar dalam dunia pendidikan. Setidaknya ada lima pergeseran yang dapat diindentifikasi dalam hubungannya dengan proses pembelajaran. Kelima pergeseran yang dimaksud dapat dijabarkan sebagai berikut: 1) Pergeseran dari pelatihan ke perbaikan kinerja, 2) Pergeseran dari uang kelas ke ruangan maya yang dapat berlangsung kapan dan di mana saja, 3) Pergeseran dari kertas ke "online" atau saluran, 4) Pergeseran fasilitas fisik ke fasilitas kerja, dan 5) Pergeseran dari waktu siklus ke waktu nyata (Yaumi, 2011: 90).

Pergeseran ini telah membawa pengaruh pada perubahan pola, metode, dan strategi penyajian pembelajaran di samping pendekatan yang digunakan juga ikut bergeser. Untuk memahami lebih jauh tentang pendekatan yang sering digunakan dalam pembelajaran, dapat dikaji melalui akronim waktu (time) dan tempat (place). Pendidikan yang menerapkan same 
time-same place (waktu yang sama-tempat yang sama), different time-same place (waktu yang berbeda-tempat yang sama), same timedifferent place (waktu yang sama-tempat yang berbeda), dan different time-different place (waktu yang berbeda-tempat yang berbeda) (Yaumi, 2011:91).

Fryer dalam Arief menyatakan bahwa penggunaan TIK dalam pembelajaran termasuk juga dalam kegiatan pendidikan dan pelatihan (diklat) bertujuan untuk melatih keterampilan menggunakan TIK dengan cara mengintegrasikannya ke dalam aktifitas pembelajaran, bukan mengajarkan TIK tersebut sebagai mata pelajaran atau mata diklat yang terpisah. Jadi, sudah saatnya TIK diintegrasikan ke dalam proses pembelajaran dan bukan hanya sekedar menjadi mata diklat yang terpisah. Pentingnya TIK pada diklat dan perlunya rumusan yang jelas tentang pemanfaatannya dalam proses pembelajaran agar dapat memberi peran dalam pencapaian tujuan diklat merupakan tugas semua pemangku kepentingan pendidikan terutama para pemegang kebijakan di lingkungan Pendidikan dan Pelatihan Kementerian Agama (Arief, 2011).

Kegiatan diklat bagi peningkatan kompetensi aparatur sipil negara (ASN) dengan memanfaatkan daya dukung TIK yang ada harus mampu mengembangkan "kualitas ASN" dalam semua aspek. Jika konsep pemanfaatannya tidak dirumuskan dengan jelas, akan dapat menimbulkan kerumitan dalam pengambilan kebijakan dalam menerapkan standar dan implementasi pengembangannya. $\mathrm{Hal}$ ini mengingat implikasi TIK sebagai produk peradaban manusia di samping memiliki sisi positif, juga mempunyai dampak negatif yang tidak kalah besarnya. Bagi sebagian kalangan, TIK justru dianggap dapat merusak sendi-sendi agama serta kontraproduktif dalam membantu membangun dan menginternalisasikan ajaran agama. Boleh jadi jika teknologi informasi tidak dimanfaatkan untuk kegiatan produktif bisa menjadi laknat, misalnya untuk mendukung pornografi dan berbagai aktivitas yang kontraproduktif (Mas'ud Ali, 2016).

Semakin berkembangnya TIK saat ini, menuntut widyaiswara sebagai fasilitator dalam proses pembelajaran di lembaga pendidikan dan pelatihan untuk mengimbangi perubahan ini secara cepat. Kegagapan teknologi bisa menjadi batu sandungan dalam proses percepatan pembelajaran dalam pelaksanaan diklat. Salah satu kompetensi widyaiswara sebagaimana diatur dalam Peraturan Kepala Lembaga Administrasi Negara (LAN) Nomor 5 Tahun 2008 tentang Instrumen Standar Kompetensi Widyaiswara adalah kompe-tensi widyaiswara dalam mengelola pembelajaran. Salah satu sub kompetensi yang harus dimiliki adalah menyusun bahan ajar. Sebagai indikator, widyaiswara harus mampu menyusun bahan ajar secara sistematis, mampu menyusun materi yang sesuai dengan tujuan pembelajaran, dan mampu menentukan referensi yang sesuai dengan materi pembelajaran. Ketiga indikator tersebut menuntut widyaiswara untuk aktif mengumpulkan informasi sebagai bahan penyusunan bahan ajar. Dengan TIK, widyaiswara bisa dengan cepat dan mudah mengumpulkan informasi yang dibutuhkan tanpa harus membuang banyak waktu untuk mencari sumber-sumber informasi secara manual. Masifnya informasi khususnya di internet akan dapat dimanfaatkan secara maksimal dalam menyusun dan mengembangkan bahan ajar yang berkualitas sekaligus up to date.

Kemudian dalam sub kompetensi selanjutnya, widyaiswara harus bisa melakukan komunikasi yang efektif dengan peserta diklat. Indikatornya, widyaiswara harus mampu menguasai teknik-teknik komunikasi secara efektif serta mampu menggunakan alat bantu secara terampil sesuai dengan situasi pembelajaran. Alat bantu untuk kebutuhan presentasi seperti Microsoft Office PowerPoint, LCD Projector, internet, dan lain-lain. Programprogram tersebut mampu menampilkan tayangan presentasi yang menarik serta mudah dibaca serta kemudahan mendapatkan informasi melalui sumber yang tidak terbatas. Mata diklat yang "kering" bisa disampaikan semenarik mungkin dengan alat bantu berbasis teknologi tersebut. Demikian pula dengan teknik-teknik komunikasi yang efektif, widyaiswara bisa berkomunikasi dengan peserta didik secara jarak jauh melalui e-learning. Widyaiswara dapat menugaskan peserta didiknya untuk mencari literatur melalui $e$-library serta membaca bahan ajar melalui e-book. Dengan demikian tidaklah 
berlebihan jika penguasaan teknologi pembelajaran menjadi kompetensi yang harus dimiliki oleh setiap widyaiswara.

Kompetensi pengelolaan pembe-lajaran merupakan sebagai salah satu kompetensi yang harus dimiliki oleh widyaiswara. Pada aspek ini, peneliti melihat masih terdapat beberapa widyaiswara yang masih memerlukan peningkatan kompetensi dalam aspek penguasaan TIK dan proses integrasinya dalam kegiatan pembelajaran di diklat. Dalam kegiatan pembelajaran pada Diklat Teknis Fungsional Peningkatan Kompetensi Pengawas Madrasah/PAI di Balai Diklat Keagamaan Makassar di tahun 2017 yang telah dilaksanakan selama 8 angkatan, peneliti melihat beberapa realitas di lapangan:

1. Sebagian widyaiswara terlihat belum memanfaatkan perangkat TIK secara bersama-sama dengan peserta diklat seperti laptop, internet, modem, dan telepon genggam (smartphone) secara terintegrasi dalam pembelajaran.

2. Kualitas bahan tayang yang cenderung monoton, kurang inter-aktif, dan jarang diperbaharui.

3. Kualitas bahan ajar diklat yang masih terdapat yang menggunakan referensi lama dan cenderung kurang diper-baharui.

4. Aplikasi pembelajaran yang diguna-kan masih terdapat yang hanya menggunakan Microsoft PowerPoint.

5. Lebih banyak menggunakan kertas dibandingkan softcopy.

6. Widyaiswara kurang mendorong, memotivasi dan menginspirasi peserta diklat untuk menggunakan perangkat TIK dalam proses pembelajaran yang efektif dan efisien.

7. Kurangnya widyaiswara mengajarkan peserta diklat tentang teknik-teknik penggunaan komputer yang efektif dalam menunjang tugas yang diberikan oleh widyaiswara.

Dalam kegiatan diklat, masih terdapat beberapa widyaiswara yang meman-faatkan komputer hanya untuk melengkapi "ceramah" mereka daripada memberi kesempatan kepada peserta diklat untuk belajar dengan memanfaatkan komputer. Widyaiswara dalam proses diklat hendaknya berhati-hati untuk tidak membuat pembelajaran yang menggunakan komputer menjadi berpusat pada widyaiswara lagi, misal dengan terlalu seringnya presentasi dengan Powerpoint dan LCD projector yang digunakan oleh widyaiswara untuk menjelaskan konsep. Bila hal tersebut kerap terjadi, maka proses pembelajaran akan tampak modern karena menggunakan perangkat TIK, tetapi sebenarnya pembelajaran tersebut sangat konvensional karena widyaiswara hanya mengandalkan ceramah (melalui powerpoint dan LCD projector) dan kegiatan peserta diklat lebih banyak mendengarkan saja.

Rumusan masalah pokok dalam penelitian ini adalah: "Bahan ajar berbasis TIK pada Diklat Pengawas Madrasah/PAl di Balai Diklat Keagamaan Makassar seharusnya menggunakan dukungan teknologi informasi komputer, tetapi pemanfaatan tidak optimal." Dari permasalahan pokok tersebut selanjutnya dideskripsikan ke dalam beberapa sub masalah sebagai berikut:

1. Bagaimana bahan ajar berbasis TIK pada Diklat Pengawas Madrasah/PAI di BDK Makassar pada aspek substansi materinya?

2. Bagaimana bahan ajar berbasis TIK pada Diklat Pengawas Madrasah/PAI di BDK Makassar pada aspek desain pembelajarannya?

3. Bagaimana bahan ajar berbasis TIK pada Diklat Pengawas Madrasah/PAI di BDK Makassar pada aspek tampilannya?

4. Bagaimana bahan ajar berbasis TIK pada Diklat Pengawas Madrasah/PAI di BDK Makassar pada aspek pemanfaatan softwarenya?

Penelitian ini memiliki tujuan untuk mengetahui bahan ajar berbasis TIK yang digunakan pada Diklat Teknis Fungsional Peningkatan Kompetensi Pengawas Madrasah/PAl di Balai Diklat Keagamaan Makassar yang meliputi aspek substansi materi, desain pembelajaran, tampilan, dan pemanfaatan software-nya.

Penelitian diharapkan memiliki kegunaan sebagai berikut:

1. Diharapkan dapat melahirkan dukungan kebijakan bagi balai diklat untuk mengedepankan integrasi TIK pada pendidikan dan pelatihan khususnya dalam penyusunan dan pengembangan bahan ajar berbasis TIK.

2. Sebagai bahan informasi bagi institusi kediklatan dalam mengembangkan ICT 
literacy para widyaiswara dan kompetensi widyaiswara menginfusikan TIK ke dalam pembelajaran termasuk berbagai strategi/metode pembe-lajaran yang efektif. Diharapkan juga widyaiswara dapat mengadopsi atau mengadaptasi strategi pembelajaran yang telah terbukti efektif dan mengomunikasikannya dengan kolega atau dapat mengembangkan sendiri. Hal ini dapat dilakukan melalui pelatihan, pengiriman mengikuti lokakarya atau seminar, terlibat aktif dalam komunitas jaringan institusi kediklatan dan lain-lain. Di samping itu, balai diklat juga harus menyiapkan tenaga teknis dalam bidang TIK untuk kegiatan kediklatan.

3. Penelitian ini diharapkan dapat menjadi rujukan bagi peneliti lain bagi penelitian kediklatan lainnya sebagai bagian yang tak terpisahkan dari pengembangan kualitas SDM aparatur sipil negara khususnya di Kementerian Agama.

\section{METODE PENELITIAN}

Penelitian ini merupakan penelitian kualitatif dengan desain studi kasus. Studi kasus merupakan sebuah eksplorasi dari "suatu sistem yang terikat" atau "suatu kasus/beragam kasus" yang dari waktu ke waktu melalui pengumpulan data yang mendalam serta melibatkan berbagai sumber informasi yang "kaya" dalam suatu konteks. Sistem terikat ini diikat oleh waktu dan tempat sedangkan kasus dapat dikaji dari suatu program, peristiwa, aktivitas atau suatu individu. (Creswell, 1998: 61).

Penelitian ini dilakukan di Balai Diklat Keagamaan Makassar pada kegiatan Diklat Teknis Fungsional Peningkatan Kompetensi Pengawas Madrasah/PAl dilaksanakan di Balai Diklat Keagamaan Makassar. Kegiatan ini dilaksanakan selama 15 hari atau selama 150 jam, yang di dalam berisi kegiatan pendidikan dan pelatihan tentang materi-materi kepengawasan, mulai dari mata diklat dasar, mata diklat inti, dan mata diklat penunjang.

Instrumen penelitian yang digunakan adalah pedoman wawancara, lembar observasi dan dokumentasi. Sedangkan tahapan pengolahan dan analisis data jenis penelitian kualitatif ini memiliki tiga komponen utama, yaitu: reduksi data, sajian data, dan penarikan kesimpulan serta verifikasi.

\section{TEMUAN DAN PEMBAHASAN}

\section{Temuan}

Komponen instrumen penelitian bahan diklat atau bahan ajar pada diklat ini mengacu pada 4 bagian, yaitu: substansi materi, desain pembelajaran, tampilan dan pemanfaatan software yang dapat dideskripsikan sebagai berikut:

\section{A. Substansi Materi}

Pada penelitian ini, bahan ajar difokuskan pada mata diklat inti pada Diklat Pengawas Madrasah/ PAI meliputi: 1) Kurikulum 2013, 2) Penyusunan Silabus dan RPP, 3) SNP, SPM dan SPMP, 4) Evaluasi Diri Sekolah/Madrasah (EDS/M), 5) Evaluasi Pendidikan, 6) Supervisi Manajerial dan penyusunan instrumen, 7) Supervisi akademik dan penyusunan instrumen, 8) Penelitian Tindakan Kepengawasan (PTKp), 9) Pendidikan Multikultural, 10) Penghitungan Angka Kredit Pengawas dan Guru, 11) Pendekatan Saintifik, 12) PKG dan PKB, dan 13) ICT.

Widyaiswara di Balai Diklat Keagamaan Makassar sebelum melaksanakan proses pembelajaran diharapkan menyusun RPBMD (Rancang Bangun Pembelajaran Mata Diklat) dan RPMD (Rencana Pembelajaran Mata Diklat), bahan ajar dan bahan tayang. Ketika widyaiswara diberikan surat tugas oleh pimpinan untuk melaksanakan pembelajaran pada diklat ini, didalamnya sudah disertakan mata diklat yang akan diajarkan, jadual dan silabus materi yang akan diajarkan. Atas dasar itulah selanjutnya widyaiswara menyusun perangkat pembelajaran tersebut.

Hal ini seperti pernyataan yang dikemukakan oleh Kepala Balai Diklat Keagamaan Makassar yang menyatakan bahwa untuk menjamin kualitas pembelajaran, setiap widyaiswara yang telah diberikan surat tugas untuk mengajar telah dilengkapi dengan silabus, sangat diharapkan untuk mempersiapkan perangkat pembelajaran seperti RBPMD, RPMD, bahan ajar dan bahan tayang yang harus disetor ke seksi masing-masing sebelum mereka melaksanakan pembelajaran. Hal yang sama 
juga dilakukan pada diklat pengawas ini, dan laporan dari seksi masing-masing setiap widyaiswara internal memang telah menyerahkan perangkat pembelajarannya sebelum mereka mengajar. Kecuali pada widyaiswara eksternal memang tidak ada kewajiban untuk mempersiapkan seluruh perangkat pembelajaran tersebut. Biasanya hanya diberikan bahan tayangnya karena itu akan digunakan oleh para panitia diklat untuk laporan pertanggung-jawabannya (Hasil wawancara, 2018).

Dari penjelasan kepala balai tersebut menunjukkan bahwa sudah ada sistem dan tradisi yang sudah baik untuk diterapkan di kampus Balai Diklat Keagamaan Makassar. Widyaiswara khususnya widyaiswara internal sebelum mengajar diharapkan dapat menyerahkan seluruh bahan diklatnya kepada setiap seksi, baik seksi tenaga teknis pendidikan dan keagamaan maupun seksi tenaga administrasi. Hal ini dilakukan untuk menjamin seorang widyaiswara dapat mengajar secara sistematis, efisien, dan efektif dalam pencapaian tujuan pembelajaran karena telah dipersiapkan semuanya secara lebih baik.

Hal ini senada dengan pernyataan widyaiswara bahwa pada semua jenis diklat termasuk Diklat Pengawas Madrasah/PAl, seluruh widyaiswara internal diharapkan menyetorkan RBPMD, RPMD, bahan ajar, dan bahan tayang ke setiap seksi sebelum mereka melaksanakan pembelajaran. Tetapi yang sering membuat perangkat pembelajaran itu dibuat tidak maksimal karena surat tugas diberikan hanya beberapa hari sebelum pelaksanaan diklat sehingga mereka hanya menyetor perangkat pembelajaran yang sudah ada sebelumnya tanpa melakukan perbaikan dan revisi untuk membuat perangkat pembelajaran secara lebih baik (Hasil wawancara, 2018).

Dari penjelasan yang dikemukakan oleh para widyaiswara tersebut dapat diketahui bahwa widyaiswara diharapkan dapat menyetorkan semua perangkat pembelajaran mereka sebelum mereka mengajar pada diklat ini. Meskipun demikian, keluhan widyaiswara tentang dekatnya waktu pemberian surat tugas mengajar dengan pelaksanaan diklat hendaknya dapat ditindaklanjuti dengan panitia diklat untuk membuat surat tugas lebih cepat sehingga perangkat pembelajaran widyaiswara dapat disiapkan secara lebih baik.

Hasil dokumentasi dari perangkat pembelajaran yang dikumpulkan peneliti, pada dasarnya hampir seluruh mata diklat pada diklat ini sudah dibuatkan RPBMD dan RPMD yang sesuai dengan silabus yang ada. Meskipun demikian, pada mata diklat pendidikan multikultural tidak terdapat perangkat pembelajaran yang dibuat oleh widyaiswara. Peneliti hanya mendapatkan bahan tayangnya tanpa ada RMPMD dan RPMD serta bahan ajar. Hal ini salah satunya disebabkan widyaiswara yang digunakan pada kegiatan ini adalah widyaiswara luar biasa yang berasal dari kalangan praktisi atau dosen dan bukan widyaiswara internal Balai Diklat Keagamaan Makassar. Meskipun demikian, dari bahan tayangnya terlihat materinya masih masuk dalam cakupan silabus yang ada.

Pada aspek bahan diklat yang digunakan widyaiswara, peneliti melihat tidak menyimpang dari kebenaran ilmu. Bahan diklat yang digunakan oleh widyaiswara menggunakan sistematika standar (template) yang sudah dibakukan oleh Lembaga Administrasi Negara. Sedangkan dari aspek isinya, sudah sesuai dengan regulasi yang ada. Hal ini dapat dilihat dari daftar literatur yang digunakan oleh widyaiwara dalam menyusun bahan diklat tersebut sudah sesuai dengan regulasi yang ada. Kajian pada bahan diklat semisal pada mata diklat Kurikulum 2013, Perhitungan Angka Kredit Pengawas dan Guru, Supervisi Akademik dan Manajerial serta penyusunan instrumennya, peneliti ketahui sudah sesuai dengan regulasi yang ada. Mata Diklat Kurikulum 2013 misalnya sudah menggunakan referensi terbaru yaitu Kurikulum 2013 Revisi 2017 yang memang ada beberapa perbedaan dengan materi Kurikulum 2013 pada tahun-tahun sebelumnya.

Sementara itu, pada mata diklat SNP, SPM, dan SPMP (Standar Nasional Pendidikan), Standar Pelayanan Minimal), 
dan Standar Penjaminan Mutu Pendidikan diketahui bahwa pada bahan diklat ini, widyaiswara masih menggunakan regulasi Permendiknas nomor 41 tahun 2007 tentang Standar Proses pada pembahasan tentang Standar Nasional Pendidikan. Padahal regulasi terbaru tentang Standar Proses sudah beberapa kali mengalami revisi mulai dari Permendikbud No. 65 Tahun 2013, Permendikbud No. 103 Tahun 2014 dan terakhir Permendikbud No. 22 Tahun 2016. Demikian juga penggunaan regulasi Permendiknas No. 23 Tahun 2006 tentang Standar Kompetensi Lulusan pada bahan ajar, padahal telah terdapat regulasi terbaru yakni Permendikbud No. 54 Tahun 2013 dan Permendikbud No. 20 Tahun 2016 tentang Standar Kompetensi Lulusan. Kondisi ini tentu berimplikasi fatal pada proses pembelajaran karena karena banyak mata diklat pada diklat ini saling terkait, seperti mata diklat Kurikulum 2013 tentu berkorelasi erat dengan mata diklat seperti Penyusunan RPP, SNP, SPM dan SPMP, Evaluasi Pendidikan, dan Pendekatan Saintifik.

Hasil dari wawancara dengan widyaiswara yang mengajar pada diklat ini menyatakan bahwa dalam membuat bahan diklat memang agak terburu-buru karena itu materi baru baginya, sementara sudah harus dikumpul di seksi sebelum mengajar. Meskipun dirinya sudah ikut TOT (Training of Trainer) Kurikulum 2013 tetapi referensinya tentang materi itu kurang up to date, tetapi sudah diperbaiki sebelum proses pembelajaran berlangsung (Hasil wawancara, 2018).

Pada aspek penggunaan tata bahasa yang baku dan dapat dimengerti (komunikatif) memang menjadi suatu permasalahan tersendiri. Beberapa bagian dari bahan tayang yang digunakan oleh widyaiswara pada mata diklat Pendidikan Multikultural terkadang tidak sesuai dengan kaidah tata bahasa Indonesia yang baku. Semisal, mereka menggunakan kata-kata asing-asing yang sebenarnya sudah ada bahasa bakunya, seperti integrated, trial and error, taken for granted atau istilah-istilah yang rumit seperti "proses konstruksi sosial multikultural", "resistensi fanatisme", "relativisme kultural dan disrupsi sosial" yang tentunya membutuhkan penjelasan secara lebih komunikatif. Penggunaan bahasabahasa akademis yang cenderung susah dimengerti maksudnya tentunya menjadi kendala tersendiri bagi peserta diklat untuk dapat memahami maksud yang diinginkan oleh widyaiswara dalam bahan tayangnya.

\section{B. Desain Pembelajaran}

Setiap item yang ditentukan dalam desain pembelajaran harus ada dalam bahan ajar yang baik. Pada bahan ajar mata diklat inti pada Diklat Pengawas Madrasah/PAI terdapat 13 mata diklat inti, terlihat beberapa bahan ajar ada yang tidak mencatumkan poin-poin tersebut. Semisal pada bahan ajar mata diklat Evaluasi Diri Sekolah/Madrasah terlihat hanya judul, materi dan daftar pustaka. Pada sampulnya dikemukakan judul, penyusun, dan instansi serta tahun pembuatan. Pada mata diklat Supervisi Manajerial dan Penyusunan Instrumennya juga tidak mencantumkan daftar pustaka yang dijadikan bahan rujukan. Meskipun pada SK-KD, indikator, materi dan latihan sudah ada. Dari 13 mata diklat inti yang diajarkan pada diklat ini, ada 4 bahan ajar yang menggunakan referensi lebih dari 10 buku dan literatur, 8 bahan ajar kurang dari 10 referensi, dan 1 bahan ajar yang tidak mencantumkan referensi dalam bahan ajar yang dibuat.

Ketika peneliti menyesuaikan antara kurikulum dan silabus yang menjadi ketentuan dari Pusdiklat Tenaga Teknis Pendidikan dan Keagamaan dengan bahan ajar yang dimiliki oleh widyaiswara pada diklat ini terdapat beberapa perbedaan, di mana pada beberapa mata diklat tidak mengikuti kurikulum dan silabus yang telah ditetapkan oleh Pusdiklat. Hal ini terkait dengan beberapa aspek:

1. Desain kurikulum dan silabus yang digunakan oleh Pusdiklat yang diikuti oleh Balai Diklat Keagamaan masih kurikulum dan silabus yang saat ini sudah mengalami perubahan. Hal ini seperti pernyataan yang dikemukakan oleh Kepala Seksi Diklat Tenaga Teknis Pendidikan dan Keagamaan BDK Makassar yang menyatakan bahwa 
terkadang kurikulum dan silabus yang dibuat oleh Pusdiklat terlambat datang ke mereka.

2. Widyaiswara terkadang tidak memperhatikan kurikulum dan silabus yang diberikan bersamaan dengan surat tugas dan membuat bahan ajar sesuai dengan data dan materi yang telah mereka miliki. Hal ini seperti pernyataan yang dikemukakan oleh widyaiswara yang menyatakan bahwa terkadang dirinya tidak merubah sama persis seperti perubahan kurikulum dan silabus yang telah diterbitkan oleh Pusdiklat. Alasannya melakukan itu karena lebih berorientasi pada kebutuhan diklat. Seperti pada mata diklat Kurikulum 2013, mereka tidak ikuti kursil karena di samping alokasi waktunya yang hanya 6 jam terus harus menjelaskan materi kurikulum 2013 yang telah banyak peserta diklat terima pada kegiatan diklat atau bimtek yang sudah pernah diikuti mereka. Jadi lebih baik menjelaskan perubahan kurikulum 2013 revisi 2017. Perubahan-perubahan apa yang telah terjadi pada kurikulum 2013 sejak awal sampai sekarang, sehingga lebih ada manfaatnya pada peserta diklat daripada harus menjelaskan kurikulum 2013 dari awal. (Hasil wawancara, 2018). Sementara widyaiswara yang lain menjelaskan bahwa kalau surat tugas datang mendadak dan sudah dekat dengan jadwal mengajar, sudah tidak sempat lagi memperhatikan silabus mata diklat yang diajarkan. Akhirnya digunakan bahan diklat dan bahan tayang yang sudah ada sebelumnya. Karena sepengetahuannya belum ada perubahan regulasi dan materi yang mata diklat yang diajarkan. (Hasil wawancara, 2018). Dari uraian tersebut bahwa penyebab widyaiswara tidak mengikuti sepenuhnya kurikulum dan silabus yang telah ditetapkan oleh Pusdiklat adalah dekatnya waktu pemberian surat tugas dengan jadual mengajar yang telah ditetapkan dan alasan kebutuhan peserta diklat yang lebih penting daripada mengikuti kurikulum dan silabus dari Pusdiklat.

3. Penyerahan perangkat pembe-lajaran yang terdiri atas RBPMD, RPMD, bahan ajar dan bahan tayang ke seksi tenaga teknis keagamaan sebelum proses pembelajaran hanya digunakan sebagai berkas administrasi. Penyerahan ini tidak memiliki implikasi dalam bentuk kontrol dan evaluasi terhadap perangkat pembelajaran tersebut serta lebih banyak digunakan untuk kebutuhan penyusunan angka kredit widyaiswara yang bersangkutan. Tidak adanya quality control, evaluasi, dan standarisasi perangkat pembelajaran yang dimiliki oleh widyaiswara membuat perangkat pembelajaran yang digunakan oleh widyaiswara BDK Makassar lebih banyak dibuat oleh individu yang bersangkutan daripada oleh sebuah tim. Jadi, pada mata diklat yang sama tetapi widyaiswara yang berbeda bisa jadi bahan ajar dan bahan tayangnya berbeda. Di samping itu, adanya keharusan pada penyusunan angka kredit widyaiswara dengan menggunakan RBPMD, RPMD, bahan ajar dan bahan tayang yang harus berbeda ketika widyaiswara mengirimkan bukti fisik ketika mereka mereka mengajarkan mata diklat yang sama. Hal ini seperti pernyataan yang dikemukakan oleh widyaiswara yang menyatakan bahwa pada penyusunan angka kredit widyaiswara, misalnya mengajarkan materi yang sama pada diklat yang sama hanya berbeda angkatan, Tim Penilai Angka Kredit Internal di Badan Litbang dan Diklat Jakarta mengharuskan RBPMD, RPMD, bahan ajar, dan bahan tayang harus berbeda. Kalau dilihat sama maka tidak dinilai dan yang dinilai hanya tatap muka yang hanya bernilai 0,04 perjam untuk widyaiswara pertama dan muda serta 0,06 perjam untuk widyaiswara madya dan utama. Di samping itu, tidak adanya evaluasi, standardisasi, dan kontrol dari pihak seksi dan kepala balai membuat bisa berimprovisasi terhadap perangkat pembelajaran yang dibuat. (Hasil wawancara, 2018). 
Sementara itu, Kepala Seksi Diklat Tenaga Teknis Pendidikan dan Keagamaan BDK Makassar menyatakan bahwa kepala balai tidak memiliki kewenangan dan perangkat yang mengontrol kualitas perangkat pembelajaran yang dimiliki oleh widyaiswara. Yang jelas widyaiswara sudah memiliki kurikulum dan silabus yang yang digunakan sebagai dasar dalam penyusunan perangkat pembelajaran yang dibagikan sebagai lampiran bersamaan dengan surat tugas mengajar mereka. Pernah dilakukan standardisasi perangkat pembelajaran yang terdiri atas RBPMD, RPMD, bahan ajar dan bahan tayang widyaiswara. Jadi pada tahun 2015 pernah dibentuk timtim yang bertugas dan bertanggung jawab untuk membuat perangkat pembelajaran sesuai dengan spesialisasi dan rumpun mata diklat mereka. Tapi itu tidak terlalu efektif karena widyaiswara sepertinya lebih menyukai menggunakan perang-kat pembelajarannya yang disusun sendiri daripada yang disusun oleh tim. Meskipun ada juga widyaiswara yang menggunakan yang disusun oleh tim (Hasil wawancara, 2018).

\section{Tampilan (komunikasi visual)}

Aspek tampilan ini lebih menyoroti pada bahan tayang yang digunakan oleh widyaiswara ketika mereka mempresentasikan materinya. Semua bahan tayang yang digunakan oleh widyaiswara di Balai Diklat Keagamaan Makassar dibuat dengan menggunakan aplikasi Microsoft PowerPoint versi 2007, 2010 dan 2013. Tidak ada bahan tayang yang dibuat oleh aplikasi lain semisal aplikasi Slideflight, Keynote, SlideRocket, atau Prezi.

Tampilan bahan tayang yang dimiliki oleh widyaiswara Balai Diklat Keagamaan Makassar dengan menggunakan aplikasi Microsoft PowerPoint memiliki tampilan standar. Tidak ada dalam bahan tayang mereka yang menggunakan fitur Microsoft PowerPoint seperti fungsi triggers, slide master, hyperlink, arabic keyboard, dan fitur tambahan seperti macromedia flash player.
Tampilan bahan tayang dengan aplikasi PowerPoint yang dimiliki oleh widyaiswara pada diklat ini tidak ada yang menggunakan navigasi yang memungkinkan perpindahan antar slide dan pembahasan secara lebih mudah dan interaktif. Pada aspek tipografi juga kebanyakan tidak memperhatikan besaran huruf dan ruang slide. Terkadang penjelasan dideskripsikan tidak dalam bentuk poin-poin tetapi seperti paragraf atau dalam bentuk kalimat panjang. Penggunaan huruf miring, warna yang berbeda, dan garis bawah pada istilah-istilah yang perlu diberikan titik tekan juga tidak ada. Demikian pula dengan besaran huruf pada slide yang terkadang terlalu kecil sehingga ketika ditampilkan tidak terlalu jelas dilihat oleh peserta diklat.

Pada aspek media yang meliputi gambar, suara, dan video yang disisipkan pada teks harus mendukung penjelasan. Kualitas gambar, suara, dan video harus yang jelas terlihat, tidak pecah tayangan videonya, dan suaranya jernih sehingga mendukung visualisasi dan tampilan presentasi. Gambar, suara, dan video harus mendukung penjelasan teks sehingga tampilan bahan tayang yang bersifat multimedia ini harus tepat dan proposional.

Hasil dokumentasi dan observasi terhadap bahan tayang yang digunakan oleh widyaiswara pada diklat ini menunjukkan beberapa aspek:

1. Sekitar $75 \%$ bahan tayang tidak menggunakan gambar, suara, dan video karena beberapa materi mata diklat memang tidak memerlukan gambar, suara dan video dalam memperjelas teks yang diberikan. Seperti pada mata diklat Supervisi Akademik dan Penyusunan Instrumen, Supervisi Manajerial dan Penyusunan Instrumen, Penyusunan Silabus dan RPP. Mata diklat-mata diklat ini memang tidak membutuhkan gambar, suara, dan video karena materinya bersifat teknis operasional. Lebih banyak bersifat praktik langsung tentang tata cara membuat RPP, membuat dan mengisi kolom-kolom yang ada dalam supervisi akademik dan supervisi manajerial. Meskipun demikian, penyisipan gambar, suara dan video tetap 
diperlukan untuk membuat kegiatan ice breaking atau games mengingat waktu pembelajaran yang sering terjadi seharian penuh bahkan terkadang sampai malam akan membuat peserta diklat jenuh.

2. Sekitar $25 \%$ bahan tayang mata diklat seperti pada mata diklat Pendekatan Saintifik, ICT, dan Pendidikan Multikultural sudah melakukan penyisipan dengan gambar, suara, dan video pada teks bahan tayang untuk memperjelas pembahasan materi yang diberikan widyaiswara. Semisal pada Mata diklat Pendekatan Saintifik yang didalamnya dijelaskan tentang pendekatan saintifik dan model-model pembelajaran memang memerlukan gambar, suara dan video yang memperjelas deskripsi misalnya tentang model pembelajaran problem based learning, project based learning, dan discovery learning. Demikian juga pada mata diklat ICT juga terdapat gambar, suara, dan video untuk memperjelas pembahasan dalam bahan tayang tersebut. Visualisasi memang harus diutamakan dalam sebuah bahan tayang, karena visualisasi jauh lebih bermakna daripada kata-kata atau sekumpulan teks. Penayangan gambar, suara dan video akan dapat membuat seorang widyaiswara dapat berbicara panjang lebar tentang materi yang disampaikan dan materi menjadi lebih kongkrit.

3. Beberapa bahan tayang kurang memperhatikan harmonisasi warna yang proporsional. Antara tulisan atau teks dengan latar belakang terlihat tidak kontras sehingga pesan terlihat kurang jelas. Terdapat juga latar belakang yang terlihat "lebih ramai" dari tulisan sehingga latar belakang justru terlihat dominan. Ini tentunya tidak baik mengingat bahwa "content is king" di mana berkualitas tidaknya bahan tayang salah satunya ditentukan oleh substansi dan konten dari bahan tayang tersebut dan bukan sekedar melihat layout atau tampilan bahan tayang. Kualitas bahan tayang tidak hanya dilihat dari tampilan yang sangat bervariatif dan menarik tetapi juga yang utama adalah pesan yang ada dalam bahan tayang harus dapat tersampaikan kepada peserta diklat. Untuk itu, harmonisasi warna yang tepat, kontras, dan jelas harus menjadi pertimbangan utama sehingga pesan dari bahan tayang tersebut terbaca dengan jelas. Meskipun demikian terdapat juga bahan tayang sudah baik. Semisal pada bahan tayang ICT yang sudah menggunakan fitur slide master dengan background yang kontras dengan tulisan sehingga pesan tersampaikan dan tampilan terlihat lebih rapi daripada yang menggunakan "tampilan PowerPoint standar" dengan background yang lebih bervariatif atau menggunakan template background standar PowerPoint.

4. Animasi diperlukan untuk membuat tampilan bahan tayang menjadi lebih menarik dan menjadi lebih hidup. Animasi dalam bahan tayang diperuntukkan untuk menunjang visualisasi sehingga dapat lebih tampil secara lebih atraktif. Meskipun demikian, dalam bahan tayang yang baik tidak boleh terlalu banyak animasi sehingga konten yang seharusnya lebih ditonjolkan menjadi lebih terkesampingkan. Pada bahan tayang digunakan oleh para widyaiswara pada diklat ini, hampir tidak ada yang menggunakan animasi. Kalaupun ada animasi hanya ada pada 2 bahan tayang, yaitu pada mata diklat ICT dan Pendekatan Saintifik. Itupun animasi yang tidak ada hubungannya dengan konten pada slide tersebut tetapi animasi yang lebih bersifat melucu untuk membuat tayangan lebih hidup.

5. Desain pada bahan tayang yang digunakan oleh widyaiswara pada diklat ini masih banyak yang bersifat sederhana. Masih banyak bahan tayang tidak ada yang menggunakan fitur seperti hyperlink, triggers, slide master. Hanya beberapa bahan tayang seperti pada mata diklat ICT dan PTKp saja yang menggunakan fitur-fitur tersebut. Bahan tayang yang lain terlihat standar, yang merupakan intisari dari bahan ajar yang digunakan widyaiswara. 
Kondisi ini senada dengan pernyataan yang dikemukakan oleh widyaiswara bahwa dirinya belum bisa mengoptimalkan fitur-fitur yang ada di PowerPoint. Dia sendiri menggunakan PowerPoint versi 2007. "Palingan yang digunakan untuk mempercantik bahan tayangnya dengan menggunakan fitur animasi dan transisi serta pengaturan huruf dan memasukkan gambar atau animasi." (Hasil wawancara, 2018).

Sementara itu, widyaiswara yang lain mengemukakan tentang bahan tayang mereka bahwa dalam pembelajarannya, bahan tayang dibuat dengan menggunakan PowerPoint. Beberapa fitur seperti slide master, hyperlink, triggers, dan lain-lain digunakan untuk memperkaya tampilan dalam bahan tayangnya. Untuk membuat soal dalam evaluasi mata diklat, digunakan fungsi triggers untuk membuat soal lebih interaktif. Demikian pula pengaturan menu pada bahan tayang, digunakan fungsi slide master, hyperlink, design, transition, dan lain-lain. Meskipun demikian, dirinya tidak mau membuat bahan tayang yang ramai karena jangan sampai tulisannya malah tidak jelas. Karena isi bahan tayang tetaplah yang harus mendapat perhatian utama. (Hasil wawancara, 2018)

\section{Pemanfaatan Software}

Aplikasi yang digunakan pada pembelajaran diklat ini semuanya menggunakan aplikasi Microsoft Office yang terdiri dari Microsoft Word, Excel, PowerPoint. Untuk mendukung pencarian data juga digunakan pula internet dengan menggunakan browser Mozilla Firefox. Pada mata diklat Penghitungan Angka Kredit Pengawas dan Guru, widyaiswara dalam membawakan materinya atau bahan tayangnya seperti biasanya menggunakan Microsoft PowerPoint. Untuk bahan praktik atau Lembar Kerja (LK) dibuatlah suatu contoh kasus tentang angka kredit pengawas dan guru kemudian peserta diklat mengerjakan LK tersebut dengan menggunakan Microsoft Excel. Dalam praktiknya, masih banyak peserta yang tidak mengerti penggunaan Excel dalam perhitungan angka kredit. Meskipun demikian, materi pada mata diklat ini peserta diklat sudah dapat memahaminya. Hal ini membuat proses penyelesaian LK terhambat karena masih banyak peserta diklat yang belum bisa menggunakan aplikasi ini. Pada kondisi ini beberapa peserta diklat yang dapat menggunakan Excel membantu temannya karena widyaiswara pada mata diklat ini juga tidak bisa membantu peserta diklat yang bermasalah dengan aplikasi Excel-nya. Meskipun akhirnya tugas yang diberikan melalui LK dapat diselesaikan pada pembelajaran mata diklat ini tapi terlihat tidak efektif karena masih ada penjelasan widyaiswara di bahan tayang yang terkesan dipercepat karena waktunya sudah habis.

Sementara itu, pada aspek orisinalitas yang menyangkut gambar/suara/video/animasi yang harus dibuat sendiri khususnya pada bahan tayang pada diklat ini sepenuhnya widyaiswara tidak ada yang membuat sendiri. Gambar/suara/video/animasi dikutip sepenuhnya dari laman berbagi video, Google Image atau internet untuk mendukung visualisasi mereka. Hal ini karena tidak ada widyaiswara di Balai Diklat Keagamaan yang memiliki keterampilan melakukan editing gambar/video/suara/animasi dengan menggunakan aplikasi seperti CorelDraw, Photoshop, Macromedia Flash atau Windows Movie Maker dan Adobe Premiere. Hal inilah yang membuat mereka memilih cara instan, semisal dengan mengedit bahan tayang yang dimiliki oleh widyaiswara lain dari Balai Diklat Keagamaan lainnya atau dengan mengambil visualisasi tersebut dari internet.

Sementara itu pada aspek keaslian bahan ajar, beberapa bahan ajar terlihat hampir sama dengan bahan ajar yang dimiliki oleh widyaiswara dari balai diklat keagamaan yang lain. Hal ini seperti pernyataan yang dikemukakan oleh widyaiswara yang menyatakan bahwa berbicara masalah keaslian bahan ajar dan bahan tayang yang digunakan widyaiswara, memang diakuinya tidak semua bahan ajar dibikin dari nol. Misalnya untuk membuat bahan tayang, kadang diambil referensi dari bahan tayang 
yang dimiliki oleh teman-teman widyaiswara dari balai diklat keagamaan lain yang memiliki kesamaan spesialisasi. Dikumpulkan beberapa bahan tayang beberapa mata diklat yang sama, kemudian diedit, baik ditambah, dikurangi, maupun diganti sesuai dengan referensi yang dimilikinya agar lebih baik (Hasil wawancara, 2018).

Sementara itu, kepala seksi tenaga teknis pendidikan dan keagamaan BDK Makassar menyatakan bahwa bahan ajar dan bahan tayang widyaiswara dalam proses pembuatannya memang tidak bisa dihindari adanya plagiasi. Intensitas pertemuan antara sesama widyaiswara, baik melalui kegiatan TOT di Jakarta maupun dalam pertemuan karena kegiatan lain membuat mereka saling barter dan saling bertukar perangkat pembelajaran yang mereka miliki. Dirinya tidak memiliki kewenangan untuk menolak bahan ajar yang diberikan ke seksi meskipun mungkin ada yang sama persis yang dimiliki oleh temannya dari balai diklat lain. Baginya, ukuran keberhasilan widyaiswara yang utama dilihat dari bagaimana mereka mampu membawakan materi yang diajarkannya secara baik. Masalah orisinalitas bahan ajar yang berasal dari widyaiswara lain tidak bisa dihindari (Hasil wawancara, 2018).

Dari pernyataan tersebut dapat diketahui bahwa dari sisi orisinalitas perangkat pembelajaran, tidak semua widyaiswara membuat perangkat pembelajaran dari awal. Meskipun demikian, ada beberapa bahan ajar dan bahan tayang widyaiswara yang peneliti ketahui merupakan karya asli yang bersangkutan. Mereka mengambil referensi dari modul, jurnal, buku serta regulasi yang berlaku sekarang untuk kemudian dibuatkan menjadi RBPMD, RPMD, bahan ajar, dan bahan tayang.

\section{Pembahasan}

Ada beberapa poin yang dapat dirumuskan dari beberapa temuan tentang bahan ajar berbasis TIK yang disusun oleh widyaiswara pada Diklat Pengawas Madrasah/PAI pada BDK Makassar, yaitu: 1) Tidak adanya quality control terhadap perangkat pembelajaran widyaiswara karena tidak adanya kewenangan bagi seksi untuk melakukan evaluasi dan kontrol terhadap perangkat pembelajaran widyaiswara, 2) Tidak adanya reward dan punishment terhadap apapun kualitas perangkat pembelajaran widyaiswara, seperti tidak boleh mengajar sebelum perangkat pembelajarannya baku atau sudah sesuai dengan kurikulum dan silabus yang telah ditetapkan atau dikurangi jam mengajarnya di kegiatan diklat yang akan datang kalau kualitas perangkat pembelajarannya rendah. 3) Tidak efektifnya pembentukan tim penyusunan standarisasi penyusunan perangkat pembelajaran bagi widyaiswara, karena tidak adanya ketentuan dan regulasi dari kepala balai bahwa widyaiswara harus menggunakan perangkat pembelajaran yang telah dibuat oleh tim tersebut, 4) Pertimbangan pragmatis yang membuat widyaiswara memiliki beberapa bentuk atau pola perangkat pembelajaran yang berbeda mulai dari RBPMD, RPMD, bahan ajar dan bahan tayang untuk mata diklat yang sama karena untuk kebutuhan penyusunan angka kredit widyaiswara. Hal ini karena ketentuannya tidak akan dinilai sebagai angka kredit kalau dengan mata diklat yang sama memiliki perangkat pembelajaran yang sama pula.

Aspek-aspek inilah yang membuat beberapa bahan diklat yang dibuat dan digunakan oleh widyaiswara tidak ada standardisasi dan terkesan asal-asalan serta hanya digunakan untuk memenuhi kewajiban administratif. Meskipun tentunya tidak semua bahan diklat yang dibuat oleh widyaiswara seperti itu. Peneliti juga melihat beberapa bahan ajar sudah cukup baik, semisal pada bahan ajar mata diklat Penelitian Tindakan Kepengawasan (PTKp) menunjukkan unsur-unsur desain pembelajaran seperti judul, SK dan KD, indikator, materi, contoh soal dan latihan, nama penyusun dan referensi yang digunakan. Demikian juga halnya dengan mata diklat ICT, Supervisi Akademik dan Penyusunan Instrumen, Supervisi Manajerial dan Penyusunan Instrumen, dan Pendekatan Saintifik. Mata diklat-mata diklat tersebut keseluruhan unsur desain pembelajaran sudah ada semua dan sesuai dengan kurikulum dan silabus yang ditetapkan oleh pusdiklat.

Kondisi bahan diklat widyaiswara yang cukup bervariatif ini disebabkan oleh beberapa hal, yaitu:

1. Belum banyaknya modul diklat yang dapat digunakan sebagai bahan diklat standar 
oleh para widyaiswara yang biasanya dibuat oleh Pusat Pendidikan dan Pelatihan Tenaga Teknis Pendidikan dan Keagamaan Jakarta.

2. Belum up to date-nya modul atau bahan diklat standar yang digunakan secara bersama oleh widyaiswara pada Balai Diklat Keagamaan di seluruh Indonesia khususnya pada diklat tenaga teknis keagamaan. Kebanyakan modul yang ada di perpustakaan BDK Makassar adalah modul lama yang sudah tidak sesuai dengan regulasi yang ada.

3. Widyaiswara dalam dalam membuat bahan diklat dilakukan secara pribadi dan tidak kolektif, baik pada tingkat Balai Diklat Keagamaan maupun pada tingkat Pusdiklat. Kondisi ini tentu berimplikasi pada tidak adanya standarisasi bahan diklat yang digunakan meskipun uraian kurikulum dan silabus sudah diberikan kepada setiap widyaiwara sebelum mereka melaksanakan pembelajaran di kelas. Meskipun pada beberapa Balai Diklat Keagamaan di daerah lain sudah membuat standarisasi bahan diklat yang dapat digunakan oleh widyaiswara di balai diklat tersebut. Pada Balai Diklat Keagamaan Makassar telah dilakukan standardisasi bahan ajar dan bahan tayang yang disusun oleh tim widyaiswara yang memiliki kesamaan spesialisasi pada tahun 2015. Meskipun demikian, para widyaiswara lebih suka menggunakan bahan diklat yang mereka bikin sendiri. Keengganan widyaiswara menggunakan perangkat pembelajaran yang dibuat oleh tim karena adanya masalah kenyamanan dan kepercayaan diri dalam membawakan materi yang dibawakan karena materi itu dibuat sendiri sehingga widyaiswara menganggap lebih memahaminya daripada yang dibuat oleh tim.

4. Tidak adanya pelatihan pembuatan dan pengembangan bahan diklat bagi widyaiswara sehingga bahan diklat yang dimiliki oleh widyaiswara tidak melalui proses pembimbingan atau validasi pakar (expert judgment) yang membuat bahan diklat ini dapat dikatakan layak atau tidak untuk dijadikan materi standar pada pembelajaran di diklat.

5. Kompetensi widyaiswara dalam membuat bahan ajar dan bahan tayang yang berbasis TIK yang bervariatif sehingga hal tersebut berimplikasi pada sumber data yang kurang ter-update dan kualitas bahan tayang yang terkadang ada yang seperti tulisan atau paragraf yang ada di Microsoft Word yang dipindah ke Microsoft PowerPoint.

6. Rendahnya minat dan motivasi widyaiswara dalam membuat bahan diklat yang berkualitas. Hal ini karena tidak adanya sistem pembinaan dan evaluasi yang sistematis dan komprehensif dari pimpinan atau pejabat yang berwenang dalam melakukan kontrol dan pembinaan terhadap kualitas bahan diklat yang dibuat dan digunakan widyaiswara dalam melakukan pembelajaran. Tidak adanya sistem kontrol dan evaluasi, baik pada tingkat Balai Diklat Keagamaan maupun pada tingkat Pusdiklat membuat widyaiswara dalam menyusun bahan ajar atau bahan tayang terkesan tidak memiliki standarisasi. Tidak pernah juga dilakukan validasi bahan ajar dalam bentuk seperti: 1 ) Diskusi dengan dengan sesama widyaiswara, 2) Seminar dengan praktisi, dan 3) Validasi dari pakar/pembimbing. Kegiatan diskusi dengan para kolega sesama widyaiswara dan para praktisi dimaksudkan untuk mendapat masukan terhadap bahan ajar yang dibuat dan dikembangkan.

7. Rendahnya intensitas Pusat Pendidikan dan Pelatihan Tenaga Teknis Pendidikan dan Keagamaan Jakarta dalam pembuatan modul atau bahan diklat standar widyaiswara yang dapat digunakan sebagai bahan diklat standar yang dapat digunakan oleh widyaiswara dalam proses pembelajarannya.

Widyaiswara dalam menyajikan bahan diklat berbasis TIK pada diklat pengawas madrasah/PAI masih mengandalkan bahan tayang yang menggunakan Microsoft PowerPoint yang berfungsi memberikan penjelasan materi pembelajaran berdasarkan poin-poin yang ada dalam bahan ajar yang telah dibuat widyaiswara. Dalam pelaksanaan pembelajaran, bahan ajar ini 
tidak dibagikan kepada peserta diklat, sehingga peserta diklat hanya menerima materi dari widyaiswara dalam bentuk bahan tayang tanpa memiliki referensi yang lebih lengkap dalam bentuk bahan ajar teks.

Proses penyajian bahan ajar dengan pola seperti itu hanya terjadi di kelas saja dan terputus pembelajarannya setelah di luar kelas. Padahal salah satu prinsip pembelajaran dengan menggunakan bahan ajar berbasis TIK adalah di mana saja, kapan saja dan siapa saja (wherever, whenever, dan whoever) yang tidak dibatasi oleh sekat-sekat waktu, tempat, dan individu. Salah satu upaya untuk menciptakan pembelajaran yang lebih luas, baik cakupan waktu, tempat, dan manusianya adalah melalui integrasi website dalam pembelajaran dilakukan secara sistemik dan lebih kompleks.

Tidak ada pembelajaran berbasis web blog sebagai tindak lanjut dari pembelajaran di kelas pada Diklat Pengawas Madrasah/PAl di sekolah. Meskipun ada website resmi BDK Keagamaan Makassar, yaitu: http://bdkmakassar.kemenag.go.id/. Pa-da website ini hanya merupakan media hubungan masyarakat (humas) yang berisi kolom tentang profil BDK Makassar, jenis kegiatan-kegiatan diklat yang dilakukan, berita-berita kediklatan, serta artikel yang berisi karya tulis ilmiah widyaiswara dan staf BDK Makassar.

Hanya ada ada 1 satu website pribadi yang dimiliki oleh widyaiswara yang melakukan pembelajaran pada diklat pengawas madrasah/PAl. Website atau blog pribadi itu berisi bahan ajar dan bahan tayang kediklatan, karya tulis ilmiah, dan beberapa kolom yang

\section{PENUTUP}

\section{Simpulan}

Penyajian bahan ajar berbasis TIK terlihat dari analisis komponen instrumen penelitian bahan ajar pada diklat ini mengacu pada 4 bagian, yaitu: 1) Substansi materi, 2) Desain pembela-jaran, 3) Tampilan (komunikasi visual), dan 4) Pemanfaatan software. Meskipun pada beberapa aspek-aspek tersebut masih memerlukan perbaikan, tetapi pada umumnya kualitas bahan ajar yang digunakan oleh widyaiswara di BDK Makassar sudah cukup baik. berisi artikel-artikel yang berhubungan dengan TIK, otomotif dan gadget. Tidak ada proses pembelajaran dalam artian ada interaksi edukatif yang dapat dilakukan pada blog pribadi tersebut. Hanya memudahkan peserta diklat untuk mengunduh dan memanfaatkan materi pembelajaran yang ada relevansinya dengan kebutuhan peserta diklat. Sebagian besar widyaiswara yang mengajar pada diklat ini tidak memiliki blog pribadi sehingga perangkat pembelajaran mereka disimpan di laptop dan membutuhkan flashdisk apabila peserta diklat menginginkan materi yang dimiliki oleh widyaiswara.

Pembelajaran online melalui website setelah selesai pembelajaran di kelas belum dilakukan pada diklat pengawas madrasah/PAI di BDK Makassar. Di samping karena persoalan sarana dan prasarana TIK, rendahnya kompetensi widyaiswara dalam pembuatan website/blog, rendahnya kompetensi TIK peserta diklat, serta struktur dan sistematika pembelajaran berbasis online melalui blog yang belum diketahui oleh widyaiswara dan peserta diklat.

Kompetensi widyaiswara dalam membuat dan mengembangkan perangkat pembelajaran, baik dalam bentuk bahan ajar maupun bahan tayang menjadi suatu keharusan. Setiap widyaiswara tidak hanya fokus pada unsur pendidikan, pengajaran dan pelatihan (dikjartih) tetapi juga aktif membuat dan mengembangkan bahan diklat, baik yang berbasis teks maupun nonteks (computer based) dalam mengoptimalkan pembelajaran sebagai upaya pencapaian tujuan diklat.

\section{Rekomendasi}

Sebagai akhir dari penelitian ini dikemukakan beberapa saran konstruktif sebagai berikut:

a. Penguasaan TIK dalam proses pembelajaran merupakan sebuah kemutlakan bagi widyaiswara di tengah globalisasi informasi dan komunikasi saat ini. TIK dengan segala implikasi positif dan negatifnya harus mampu diarahkan secara maksimal oleh widyaiswara untuk menunjang proses pembelajaran yang dilakukan. Widyaiswara tidak boleh egois dengan hanya memiliki ketrampilan penguasaan TIK untuk dirinya sendiri, tetapi yang lebih penting adalah 
bagaimana fasilitas TIK yang ada di lingkungan belajar itu bisa digunakan secara optimal untuk pembelajaran di kelas. Untuk itu, widyaiswara tidak hanya harus selalu meng-upgrade kemampuannya dalam penguasaan TIK, tetapi juga harus selalu belajar bagaimana meningkatkan kemampuan dalam memanfaatkan fasilitas TIK yang melibatkan peserta diklat untuk menunjang proses pembelajaran.

b. Hendaknya dapat dibentuk tim dalam widyaiswara yang secara kolaboratif dapat menyusun bahan diklat standar yang dapat digunakan secara bersama oleh para widyaiswara. Dipresentasikan, ditelaah bersama dan dianalisis, baik substansinya maupun komunikasi visualnya serta dapat dilakukan penilaian oleh para pakar dibidangnya.

c. Kepala BDK Makassar hendaknya mendorong para widyaiswara dalam penyusunan dan pengembangan bahan ajar berbasis TIK secara riil dengan memberikan anggaran yang dapat digunakan pengembangan kualitas SDM widyaiswara dalam bentuk bimbingan teknis penyusunan dan pengembangan bahan ajar berbasis TIK. 


\section{DAFTAR PUSTAKA}

Arief, Z. (2011). Pengintegrasian Teknologi Informasi dan KomunikasipPada Proses Pembelajaran Di Balai Diklat Keagamaan. $\ln$ balitbangdiklat.kemenag.go.id. https://balitbangdiklat.kemenag.go.id/berita/pengintegrasian-teknologi-informasi-dan-komunikasipada-proses-pembelajaran-di-balai-diklat-keagamaan

Badan Pengembangan dan Pembinaan Bahasa Kementerian Pendidikan dan Kebudayaan RI. 2016. Kamus Besar Bahasa Indonesia Edisi Kelima. kbbi.kemdikbud.go.id.

Creswell, John W. 1998. Qualitative Inquiry and Research Design: Choosing Among Five Tradition. London: SAGE Publications.

Direktorat Pembinaan SMA. 2010. Panduan Pengembangan Bahan Ajar Berbasis TIK. Jakarta: Kementerian Pendidikan Nasional Irektorat Jenderal Manajemen Pendidikan Dasar Dan Menengah.

Fakhruddin, M., Ananda, R., \& Istiningsih, S. (2013). PERUBAHAN PARADIGMA DALAM ORGANISASI BELAJAR DI ABAD 21. Perspektif Ilmu Pendidikan, 27(2), 110-117. https://doi.org/10.21009/pip.272.5

Hasan, A. A., Sunan, U., Yogyakarta, K., \& Baroroh, U. (2019). PENGEMBANGAN MEDIA PEMBELAJARAN BAHASA ARAB MELALUI APLIKASI VIDEOSCRIBE DALAM MENINGKATKAN MOTIVASI BELAJAR SISWA. In LISANUNA (Vol. 9, Issue 2). https://jurnal.ar-raniry.ac.id/index.php/lisanuna/article/view/6738

Mas'ud Ali, K. (2016). INTEGRITAS PENDIDIKAN AGAMA ISLAM TERHADAP ILMU PENGETAHUAN DAN TEKNOLOGI Abstrak. In Tadrib: Vol. II (Issue 1). http://jurnal.radenfatah.ac.id/index.php/Tadrib/article/view/1158

Kementerian Agama RI. 2007. Al-Qur'an dan Terjemahnya. Semarang: CV. Toha Putra.

Peraturan Kepala LAN No. 5 Tahun 2008 tentang Standar Kompetensi Widyaiswara.

Peraturan Kepala Lembaga Administrasi Negara No. 26 Tahun 2015 tentang Pedoman Penilaian Angka Kredit Jabatan Fungsional Widyaiswara.

Peraturan Kepala Lembaga Administrasi Negara No. 5 Tahun 2008 tentang Standar Kompetensi Widyaiswara.

Peraturan Menteri Pendidikan Nasional No. 16 Tahun 2007 tentang Standar Kualifikasi Akademik dan Kompetensi Guru. Jakarta: Sinar Grafika.

Rusman, dkk. 2011. Pembelajaran Berbasis Teknologi Informasi dan Komunikasi; Mengembangkan Profesionalitas Guru. Cet. I; Jakarta: PT. RajaGrafindo Persada.

Sudjana, Nana. 1989. Dasar-dasar Proses Belajar Mengajar. Bandung: Sinar Baru Algesindo.

Yaumi, M. (2011). INTEGRASI TEKNOLOGI INFORMASI DAN KOMUNIKASI DALAM PEMBELAJARAN. Lentera Pendidikan: Jurnal Ilmu Tarbiyah Dan Keguruan, 14(1), 88-102. https://doi.org/10.24252/lp.2011v14n1a6 